Nuraisah, A. · C. Suherman · M. Ariyanti · A. Nuraini · M.A. Soleh

\title{
Pertumbuhan, hasil, dan karakter fisiologis padi yang diberi pupuk hayati pada pertanaman kelapa sawit belum menghasilkan I
}

\section{Growth, yield, and physiological traits on rice that was applied organic fertilizer under palm oil plant at immature plants stages I}

Diterima : 28 Maret 2019/Disetujui : 27 Desember 2019 / Dipublikasikan : 31 Desember 2019

CDepartment of Crop Science, Padjadjaran University

\begin{abstract}
Open space among palm oil trees at IPS I could be used for growing annual crops such as rice for supporting food sufficiency national program. This study was to obtain proper organic fertilizer dosages for improving best plant growth and yield of rice under palm oil trees at IPS I. The experiment was conducted at experimental station of Faculty of Agriculture, Padjadjaran University from December 2017 to April 2018. The experimental design was Randomized Block with six treatments of fertilizer dosage: 0, 75, 100, 125, 150, 175 $\mathrm{mL} /$ plant. Each treatment was replicated four times. The application of organic fertilizer affected on filled grains number, grains weight per plant, and 100 grains weight. The dosage of $100 \mathrm{~mL} /$ plants had good trend on morphological and physiological traits of rice. Oil palm growth did not affected by rice cultivation between oil palm areas.
\end{abstract}

Keywords: Intercropping - Organic fertilizer • Physiological traits

Sari ruang terbuka diantara tanaman kelapa sawit belum menghasilkan dapat dimanfaatkan untuk budidaya tanaman pangan, khususnya padi sebagai tanaman sela dalam rangka mendukung program ketahanan nasional. Penelitian dilakukan dengan tujuan untuk memperoleh dosis pupuk hayati yang berpengaruh paling baik terhadap pertumbuhan, hasil, dan karakter fisiologis tanaman padi yang ditanam pada pertanaman kelapa sawit TBM 1 serta melihat dampak penanaman padi sebagai tanaman sela terhadap

\footnotetext{
Dikomunikasikan oleh Yuyun Yuwariah dan Aep Wawan Irwan

Nuraisah. A $^{1}$. C. Suherman ${ }^{1}$. M. Ariyanti ${ }^{1}$ A.Nuraini ${ }^{1}$ M.A. Soleh ${ }^{1}$

Fakultas Pertanian, Universitas Padjadjaran

Jl.Raya Jatinangor Km.21 Jatinangor, Sumedang 45363

Korespondensi : cucu.suherman@unpad.ac.id
}

pertumbuhan kelapa sawit. Percobaan dilakukan di Kebun Percobaan Ciparanje, Fakultas Pertanian, Universitas Padjadjaran, pada bulan Desember 2017 sampai bulan April 2018. Percobaan disusun menggunakan Rancangan Acak Kelompok (RAK) yang terdiri dari enam perlakuan dosis pupuk hayati, yaitu 0, 75, 100, 125, 150, $175 \mathrm{~mL} /$ tanaman. Setiap perlakuan diulang empat kali sehingga terdapat 24 unit percobaan. Hasil penelitian menunjukkan dosis pupuk hayati berpengaruh terhadap jumlah gabah isi, bobot gabah per tanaman, dan bobot gabah 100 butir yang di tanam pada pertanaman kelapa sawit saat tanaman belum menghasilkan (TBM 1). Dosis pupuk hayati $100 \mathrm{~mL} /$ tanaman cenderung memberikan pengaruh baik terhadap karakter morfologis dan fisiologis padi. Pertumbuhan tanaman kelapa sawit tidak dipengaruhi oleh budidaya padi sebagai tanaman sela.

Kata kunci: Karakter fisiologis • Pupuk hayati • Tumpangsari.

\section{Pendahuluan}

Padi (Oryza sativa L.) merupakan salah satu jenis tanaman yang memegang peranan penting di Indonesia dalam memenuhi kebutuhan pangan. Salah satu sistem budidaya padi (Oryza sativa L.) yaitu budidaya padi gogo di lahan kering. Padi gogo adalah padi yang ditanam pada lahan kering yang sepanjang siklus hidupnya tidak digenangi air dan sumber kebutuhan airnya berasal dari kelembaban tanah dan curah hujan (Sumarno dan Hidajat, 2007). Salah satu lahan yang dapat dimanfaatkan untuk penanaman padi gogo adalah ruang terbuka di antara tanaman kelapa sawit TBM I yang mencapai luas $75 \%$. Kelapa sawit umumnya ditanam pada 
tanah-tanah marginal yang memiliki keterbatasan dalam hal kesuburan fisik, kimia, dan biologi tanah. Oleh karena itu, penanaman padi gogo secara tumpangsari pada kelapa sawit TBM 1 perlu memperhatikan permasalahan yang berkaitan dengan faktor kesuburan tanahnya sehingga perlu dilakukan pemupukan yang optimal, diantaranya aplikasi pupuk hayati.

Pupuk hayati adalah pupuk yang mengandung inokulan berbahan aktif organisme hidup, yaitu mikroba yang menguraikan atau mengikat unsur hara sehingga unsur hara tersebut dapat tersedia dalam tanah dan dimanfaatkan oleh tanaman (Sumihar, 2012). Pupuk hayati Bion-Up adalah pupuk hayati yang berisi beberapa mikroba potensial, diantaranya mikroba pemfiksasi nitrogen (Azotobacter chooroccum, Azotobacter vinelandli, Azospririllium sp dan Acinetobacter sp) serta bakteri pelarut fosfat Pseudomonas capacia dan jamur pelarut fosfat Penicillium sp. Penggunaan pupuk hayati merupakan bagian dari sistem produksi pertanian organik (Simanungkalit, 2000). Penggunaan pupuk organik dan pupuk hayati selain dapat meningkatkan pertumbuhan tanaman, hasil, dan kualitas hasil tanaman cabai (Ghoname dan Shafeek, 2005, Reyes et al., 2008, Malgorzata dan Georgios, 2008, Fawzy et al., 2012, Zafar et al., 2011), juga dapat mengurangi penggunaan pupuk NPK (Suwandi dan Rosliani, 2004; Widawati et al., 2010, Suliasih et al., 2010, Suwandi et al., 2015). Pupuk hayati mengandung mikroorganisme hidup, penambahan ke dalam tanah dalam bentuk inokulan atau bentuk lain mampu meningkatkan ketersediaan unsur hara bagi tanaman. Aplikasi pupuk hayati pada tanaman padi sebagai tanaman sela kelapa sawit di lahan marjinal diharapkan dapat memperbaiki pertumbuhan tanaman padi.

\section{Bahan dan Metode}

Bahan yang digunakan dalam penelitian ini antara lain: benih padi gogo kultivar Situ Bagendit, Pertanaman kelapa sawit TBM I umur 6 bulan persilangan Dura dumpy X Pisifera Avros yaitu varietas SEU Supreme Mekar Sari, pupuk hayati cair Bion-Up, pupuk kompos UNPAD, pupuk urea, SP-36, dan KCl. Alat yang digunakan diantaranya timbangan, gunting, alat tulis, meteran cangkul, koret, sprayer, ember plastik, leaf porometer (Model SC-1, Decagon Devices), lux meter, klorofil meter (CCM-200, Apogee Instruments Inc).
Penanaman kelapa sawit menggunakan jarak tanam $8 \mathrm{~m} \times 8 \mathrm{~m}$, sehingga populasi tanaman sebanyak 156 tanaman/ha. Penanaman tanaman sela padi gogo dengan jarak tanam 20 $\mathrm{cm} \times 20 \mathrm{~cm}$. Varietas padi gogo yang digunakan adalah varietas Situ Bagendit yang diperoleh dari BBP Padi Sukamandi. Lubang tanam dibuat dengan cara ditugal kedalaman $3 \mathrm{~cm}$. Penanaman sebanyak tiga benih per lubang tanam. Sebelum ditanami, lubang tanam ditaburi furadan terlebih dahulu.

Rancangan percobaan yang digunakan adalah Rancangan Acak Kelompok (RAK). Terdiri atas enam perlakuan taraf dosis pupuk hayati, yaitu $0,75,100,125,150,175 \mathrm{~mL} /$ tanaman. Pupuk hayati dilarutkan dalam $1 \mathrm{~L}$ air dan disiramkan pada tanaman saat awal tanam. Semua perlakuan diulang sebanyak 4 kali. Total 24 satuan percobaan.

Pengamatan terhadap tanaman padi gogo terdiri dari beberapa parameter meliputi: pertumbuhan, komponen hasil, dan karakter fisiologis tanaman padi gogo yaitu:

1. Pertumbuhan, meliputi tinggi tanaman dan jumlah anakan,

2. Komponen hasil, terdiri atas jumlah malai, jumlah gabah isi, jumlah gabah hampa, bobot gabah per tanaman, dan bobot gabah 100 butir,

3. Karakter fisiologis, yaitu indeks kandungan klorofil dan konduktansi stomata. Kandungan klorofil dan konduktansi stomata diukur pada akhir fase vegetatif dan generatif.

4. Pertumbuhan kelapa sawit, terdiri dari tinggi tanaman, jumlah daun, dan diameter lilit batang. Pengamatan dilakukan agar dapat dilihat efek dari penanaman padi terhadap pertumbuhan sawit.

\section{Hasil dan Pembahasan}

Pertumbuhan Tanaman Padi (Oryza sativa L.). Hasil analisis statistik menunjukkan bahwa perlakuan dosis pupuk hayati tidak menghasilkan pengaruh yang berbeda nyata terhadap tinggi tanaman (Tabel 1), maupun terhadap jumlah anakan (Tabel 2).

Tabel 1 menunjukkan bahwa pada pengamatan 8, 10, dan 12 minggu setelah tanam (MST), perlakuan dosis pupuk hayati tidak memberikan pengaruh yang berbeda nyata terhadap tinggi tanaman, tetapi di akhir 
pengamatan terdapat kecenderungan dosis 100-125 mL/tanaman menghasilkan tinggi yang baik. Bila dibandingkan dengan deskripsi, tinggi tersebut masih jauh dari potensinya. Hasil percobaan ini menunjukkan bahwa pertumbuhan tinggi tanaman padi gogo belum optimal.

Tabel 1. Pengaruh dosis pupuk hayati terhadap tinggi tanaman padi gogo varietas Situ Bagendit umur 8, 10, 12 MST yang ditanam pada pertanaman kelapa sawit TBM 1.

\begin{tabular}{lccc}
\hline Dosis pupuk hayati & \multicolumn{3}{c}{ Tinggi Tanaman (cm) Padi } \\
\cline { 2 - 4 } & $8 \mathrm{MST}$ & 10MST & 12MST \\
\hline $0 \mathrm{~mL} /$ tanaman & $26,80 \mathrm{a}$ & $29,26 \mathrm{a}$ & $39,37 \mathrm{a}$ \\
$75 \mathrm{~mL} /$ tanaman & $28,75 \mathrm{a}$ & $29,57 \mathrm{a}$ & $40,33 \mathrm{a}$ \\
$100 \mathrm{~mL} /$ tanaman & $29,76 \mathrm{a}$ & $31,73 \mathrm{a}$ & $41,12 \mathrm{a}$ \\
$125 \mathrm{~mL} /$ tanaman & $29,20 \mathrm{a}$ & $31,33 \mathrm{a}$ & $41,81 \mathrm{a}$ \\
$150 \mathrm{~mL} /$ tanaman & $30,03 \mathrm{a}$ & $29,86 \mathrm{a}$ & $40,00 \mathrm{a}$ \\
$175 \mathrm{~mL} /$ tanaman & $26,53 \mathrm{a}$ & $30,17 \mathrm{a}$ & $38,96 \mathrm{a}$ \\
\hline
\end{tabular}

Keterangan :Nilai rata-rata perlakuan yang ditandai dengan huruf yang sama pada kolom yang sama tidak berbeda nyata berdasarkan Uji Jarak Berganda Duncan pada taraf nyata $5 \%$

Pertumbuhan vegetatif yang optimal hanya akan terjadi jika faktor pertumbuhan tanaman tersebut tercukupi dengan baik.

Hasil yang tidak berbeda nyata terhadap tinggi tanaman (Tabel 1), juga terjadi pada jumlah anakan padi (Tabel 2). Perlakuan do kondisi tinggi tanaman yang tidak berbeda nyata, terjadi karena kurang terpenuhinya kebutuhan unsur hara tanaman dari pupuk hayati yang belum optimal dosisnya.sis pupuk hayati juga tidak menghasilkan pengaruh yang berbeda nyata terhadap jumlah anakan.
Tabel 2. Pengaruh dosis pupuk hayati terhadap jumlah anakan tanaman padi gogo varietas Situ Bagendit umur 8, 10, 12 MST yang ditanam pada pertanaman kelapa sawit TBM 1.

\begin{tabular}{lccc}
\hline \multirow{2}{*}{ Perlakuan } & \multicolumn{3}{c}{ Jumlah Anakan Padi } \\
\cline { 2 - 4 } & $8 \mathrm{MST}$ & $10 \mathrm{MST}$ & $12 \mathrm{MST}$ \\
\hline $0 \mathrm{~mL} /$ tanaman & $3,66 \mathrm{a}$ & $9,45 \mathrm{a}$ & $12,76 \mathrm{a}$ \\
$75 \mathrm{~mL} /$ tanaman & $4,05 \mathrm{a}$ & $10,04 \mathrm{a}$ & $14,06 \mathrm{a}$ \\
$100 \mathrm{~mL} /$ tanaman & $3,99 \mathrm{a}$ & $10,78 \mathrm{a}$ & $15,29 \mathrm{a}$ \\
$125 \mathrm{~mL} /$ tanaman & $3,91 \mathrm{a}$ & $10,66 \mathrm{a}$ & $13,50 \mathrm{a}$ \\
$150 \mathrm{~mL} /$ tanaman & $5,02 \mathrm{a}$ & $10,99 \mathrm{a}$ & $14,81 \mathrm{a}$ \\
$175 \mathrm{~mL} /$ tanaman & $4,63 \mathrm{a}$ & $10,61 \mathrm{a}$ & $13,42 \mathrm{a}$ \\
\hline
\end{tabular}

Keterangan :Nilai rata-rata perlakuan yang ditandai dengan huruf yang sama pada kolom yang sama tidak berbeda nyata berdasarkan Uji Jarak Berganda Duncan pada taraf nyata 5

Pertumbuhan anakan berlangsung sejak munculnya anakan pertama sampai pembentukan anakan maksimum. Anakan terus berkembang sampai tanaman memasuki tahap pemanjangan batang dan fase primordia (Makarim dan Suhartatik, 2009). Menurut Riyani et al. (2013), mikroba pelarut fosfat yang terkandung dalam pupuk hayati dapat berfungsi meningkatkan $\mathrm{P}$ tersedia bagi tanaman. Unsur $\mathrm{P}$ berperan penting dalam meningkatkan kerja kloroplas sebagai penyerap sinar matahari dalam fotosintesis. Selain itu, unsur $\mathrm{P}$ juga berperan aktif mentransfer energi di dalam sel. Energi yang dihasilkan sangat penting dalam proses pembelahan sel untuk membentuk anakan. Hanya dalam percobaan ini, data menunjukkan berbagai mikroorganisme yang dikandung pupuk hayati tidak menghasilkan pertumbuhan anakan yang berbeda nyata.

Tabel 3. Pengaruh dosis pupuk hayati terhadap jumlah malai, jumlah gabah bernas, jumlah gabah hampa, bobot gabah per tanaman, bobot gabah 100 butir tanaman padi gogo varietas Situ Bagendit umur 14 MST yang ditanam pada pertanaman kelapa sawit TBM 1.

\begin{tabular}{lccccccc}
\hline & \multicolumn{7}{c}{ Komponen hasil 14 MST } \\
\cline { 2 - 7 } Perlakuan & $\begin{array}{c}\text { Jumlah } \\
\text { malai }\end{array}$ & $\begin{array}{c}\text { Jumlah } \\
\text { gabah } \\
\text { isi }\end{array}$ & $\begin{array}{c}\text { Bobot } \\
\text { gabah/sa } \\
\text { mpel }(\mathrm{g})\end{array}$ & $\begin{array}{c}\text { Bobot } \\
\text { gabah } \\
100 \mathrm{butir} \\
(\mathrm{g})\end{array}$ & $\begin{array}{c}\text { Jumlah } \\
\text { gabah } \\
\text { hampa }\end{array}$ & $\begin{array}{c}\text { Bobot } \\
\text { gabah/ } \\
\text { tanaman } \\
(\mathrm{g})\end{array}$ & $\begin{array}{c}\text { Bobot } \\
\text { gabah } \\
100 \mathrm{butir} \\
(\mathrm{g})\end{array}$ \\
\hline $0 \mathrm{~mL} /$ tanaman & $12,00 \mathrm{a}$ & $163,04 \mathrm{a}$ & $7,38 \mathrm{a}$ & $4,00 \mathrm{a}$ & $73,72 \mathrm{a}$ & $7,38 \mathrm{a}$ & $4,00 \mathrm{a}$ \\
$75 \mathrm{~mL} /$ tanaman & $11,98 \mathrm{a}$ & $169,45 \mathrm{a}$ & $6,49 \mathrm{a}$ & $4,25 \mathrm{a}$ & $79,82 \mathrm{a}$ & $6,49 \mathrm{a}$ & $4,25 \mathrm{a}$ \\
$100 \mathrm{~mL} /$ tanaman & $12,90 \mathrm{a}$ & $192,20 \mathrm{a}$ & $8,12 \mathrm{a}$ & $4,00 \mathrm{a}$ & $64,18 \mathrm{a}$ & $8,12 \mathrm{a}$ & $4,00 \mathrm{a}$ \\
$125 \mathrm{~mL} /$ tanaman & $11,70 \mathrm{a}$ & $173,39 \mathrm{a}$ & $7,09 \mathrm{a}$ & $4,25 \mathrm{a}$ & $53,29 \mathrm{a}$ & $7,09 \mathrm{a}$ & $4,25 \mathrm{a}$ \\
$150 \mathrm{~mL} /$ tanaman & $12,59 \mathrm{a}$ & $156,11 \mathrm{a}$ & $6,24 \mathrm{a}$ & $4,25 \mathrm{a}$ & $44,51 \mathrm{a}$ & $6,24 \mathrm{a}$ & $4,25 \mathrm{a}$ \\
$175 \mathrm{~mL} /$ tanaman & $11,54 \mathrm{a}$ & $102,62 \mathrm{~b}$ & $3,47 \mathrm{~b}$ & $3,00 \mathrm{~b}$ & $63,12 \mathrm{a}$ & $3,47 \mathrm{~b}$ & $3,00 \mathrm{~b}$ \\
\hline
\end{tabular}

Keterangan : Nilai rata-rata perlakuan yang ditandai dengan huruf yang sama pada kolom yang sama tidak berbeda nyata berdasarkan Uji Jarak Berganda Duncan pada taraf nyata 5\%; MST = Minggu Setelah Tanam 
Komponen Hasil (jumlah malai, jumlah gabah bernas, jumlah gabah hampa, bobot gabah per tanaman, bobot gabah 100 butir). Tabel 3 menunjukkan bahwa terdapat perlakuan pupuk hayati yang menghasilkan komponen hasil (jumlah gabah bernas, bobot gabah per sampel, dan bobot gabah 100 butir) yang berbeda nyata. Perlakuan pupuk hayati tertinggi (175 $\mathrm{mL} /$ tanaman) menghasilkan nilai komponen hasil paling rendah dibandingkan dengan pengaruh perlakuan lainnya, bahkan lebih kecil dibandingkan dengan pengaruh perlakuan tanpa pupuk hayati. Hal ini diduga terjadi karena konsentrasi mikroorganisme terlalu banyak pada perlakuan pupuk hayati $175 \mathrm{~mL} /$ tanaman, sehingga terjadi kompetisi diantara mikroorganisme dalam memenuhi kebutuhan hidupnya, yang berakibat mikroorganisme tidak berfungsi sebagaimana yang diharapkan. Kemampuan mikroba dalam membantu menyediakan unsur hara terutama $\mathrm{N}$ dan $\mathrm{P}$ bagi tanaman padi menjadi tidak optimal. Pemberian pupuk hayati yang berlebihan akan menyebabkan terjadinya persaingan antar mikroba dalam memperoleh makanan sehingga akan berpengaruh terhadap tanaman.

Hasil penelitian Wardhani et al. (2014), menunjukkan bahwa, pemberian pupuk hayati yang terlalu banyak berakibat terhadap kandungan mikroorganisme yang ada di dalam tanah menjadi terlalu banyak. Banyaknya populasi mikroorganisme tersebut menyebabkan terjadinya kompetisi antar mikroorganisme dalam mendapatkan kecukupan kebutuhan makanan, oksigen, dan air. Kurangnya kebutuhan tersebut bagi mikroorganisme menyebabkan organisme tersebut mudah mati

Karakter Fisiologis Tanaman Padi (Indeks Kandungan Klorofil (CCI) dan Konduktansi Stomata $\left.\left(\mathrm{mmol}^{\mathrm{m}} \mathrm{m}^{2} \mathrm{~S}\right)\right)$. Hasil analisis data pengaruh pupuk hayati terhadap karakter fisiologis (kandungan klorofil (Tabel 4) dan konduktansi stomata (Tabel 5)), menuunjukkan bahwa konsentrasi pupuk hayati tidak menghasilkan pengaruh yang berbeda nyata terhadap karakter fisiologis tanaman padi gogo yang ditanam pada pertanaman kelapa sawit TBM I. Tidak berbedanya rata-rata antar perlakuan disebabkan variasi klorofil yang sangat beragam diantara perlakuan. Kandungan/Jumlah klorofil merupakan salah satu tolak ukur laju fotosintesis. Jumlah klorofil dapat digunakan untuk mengidentifikasi tingkat pertumbuhan dan kesuburan tanaman dan dapat dikaitkan dengan prediksi produksi dari tanaman tersebut (Atmanegara dan Bangun, 2013). Kurniawan et al. (2010), menyatakan juga bahwa biosintesis klorofil dibawakan oleh gengen tertentu di dalam kromosom, gen-gen tersebut menyandi enzim yang akan berperan dalam jalur biosintesis tetrapirol (inti porpirin) sebagai pusat struktur dari klorofil.

Tabel 4. Pengaruh dosis pupuk hayati terhadap indeks kandungan klorofil (CCI) padi gogo varietas Situ Bagendit masa vegetatif dan generatif yang ditanam pada pertanaman kelapa sawit TBM 1.

\begin{tabular}{|c|c|c|}
\hline \multirow{2}{*}{ Perlakuan } & \multicolumn{2}{|c|}{$\begin{array}{l}\text { Indeks Kandungan Klorofil } \\
(\mathrm{CCI})\end{array}$} \\
\hline & $\begin{array}{l}\text { Masa } \\
\text { vegetatif }\end{array}$ & $\begin{array}{l}\text { Masa } \\
\text { generatif }\end{array}$ \\
\hline $0 \mathrm{~mL} /$ tanaman & $41,8 \mathrm{a}$ & $27,34 \mathrm{a}$ \\
\hline 75 mL/tanaman & $32,30 \mathrm{a}$ & $43,50 \mathrm{a}$ \\
\hline $100 \mathrm{~mL} /$ tanaman & $24,40 \mathrm{a}$ & $51,29 \mathrm{a}$ \\
\hline $125 \mathrm{~mL} /$ tanaman & $20,00 \mathrm{a}$ & 83,01 a \\
\hline $150 \mathrm{~mL} /$ tanaman & $17,80 \mathrm{a}$ & $19,72 \mathrm{a}$ \\
\hline $175 \mathrm{~mL} /$ tanaman & $7,95 \mathrm{a}$ & $42,31 \mathrm{a}$ \\
\hline
\end{tabular}

Keterangan: Nilai rata-rata perlakuan yang ditandai dengan huruf yang sama pada kolom yang sama tidak berbeda nyata berdasarkan Uji Jarak Berganda Duncan pada taraf nyata 5\%

Tabel 5. Pengaruh dosis pupuk hayati terhadap konduktansi stomata $\left(\mathrm{mmol} / \mathrm{m}^{2} \mathrm{~S}\right)$ padi gogo varietas Situ Bagendit umur 12 MST yang ditanam pada pertanaman kelapa sawit TBM 1 .

\begin{tabular}{lll}
\hline & \multicolumn{2}{c}{$\begin{array}{c}\text { Konduktansi Stomata } \\
\text { Perlakuan }\end{array}$} \\
\cline { 2 - 3 } & $\begin{array}{l}\text { Masa } \\
\text { vegetatif }\end{array}$ & $\begin{array}{l}\text { Masa } \\
\text { generatif }\end{array}$ \\
\hline p0: Tanpa pupuk hayati & $162,56 \mathrm{a}$ & $154,00 \mathrm{a}$ \\
p1: $75 \mathrm{~mL} /$ tanaman & $227,96 \mathrm{a}$ & $164,00 \mathrm{a}$ \\
p2: $100 \mathrm{~mL} /$ tanaman & $220,06 \mathrm{a}$ & $188,00 \mathrm{a}$ \\
p3: $125 \mathrm{~mL} /$ tanaman & $199,82 \mathrm{a}$ & $167,00 \mathrm{a}$ \\
p4: $150 \mathrm{~mL} /$ tanaman & $169,40 \mathrm{a}$ & $112,47 \mathrm{a}$ \\
p5: $175 \mathrm{~mL} /$ tanaman & $141,24 \mathrm{a}$ & $132,00 \mathrm{a}$ \\
\hline
\end{tabular}

Keterangan : Nilai rata-rata perlakuan yang ditandai dengan huruf yang sama pada kolom yang sama tidak berbeda nyata berdasarkan Uji Jarak Berganda Duncan pada taraf nyata $5 \%$; MST = Minggu Setelah Tanam

Konduktansi stomata adalah gambaran jumlah stomata yang terbuka, sebagai respons terhadap kondisi lingkungan. Secara umum, stomata akan tertutup (jumlah stomata terbuka akan sedikit), sebagai respons terhadap cekaman 
Tabel 6. Pengaruh tumpangsari tanaman kelapa sawit dan padi gogo varietas Situ Bagendit terhadap rata-rata tinggi tanaman, jumlah daun, dan lilit batang kelapa sawit umur 6, 7, 8 dan 9 bulan $(0,1,2,3$ bulan setelah penanaman (BSP) tanaman padi).

\begin{tabular}{clrrrr}
\hline \multirow{2}{*}{ Parameter } & \multirow{2}{*}{ Perlakuan } & \multicolumn{4}{c}{ Pertumbuhan kelapa sawit } \\
\cline { 3 - 5 } & & \multicolumn{1}{c}{0 BSP } & 1 BSP & 2 BSP & 3 BSP \\
\hline \multirow{2}{*}{ Tinggi Tanaman (cm) } & Kelapa sawit & $125,50 \mathrm{a}$ & $126,84 \mathrm{a}$ & $127,70 \mathrm{a}$ & $128,20 \mathrm{a}$ \\
& Kelapa sawit + Padi & $123,13 \mathrm{a}$ & $123,81 \mathrm{a}$ & $124,94 \mathrm{a}$ & $126,12 \mathrm{a}$ \\
\hline \multirow{2}{*}{ Jumlah Daun (helai) } & Kelapa sawit & $6,50 \mathrm{a}$ & $6,75 \mathrm{a}$ & $6,75 \mathrm{a}$ & $6,75 \mathrm{a}$ \\
& Kelapa sawit + Padi & $6,62 \mathrm{a}$ & $6,69 \mathrm{a}$ & $6,69 \mathrm{a}$ & $6,69 \mathrm{a}$ \\
\hline \multirow{2}{*}{ Lilit Batang (cm) } & Kelapa sawit & $9,47 \mathrm{a}$ & $9,71 \mathrm{a}$ & $9,95 \mathrm{a}$ & $10,33 \mathrm{a}$ \\
& Kelapa sawit + Padi & $10,17 \mathrm{a}$ & $10,72 \mathrm{a}$ & $10,96 \mathrm{a}$ & $11,16 \mathrm{a}$ \\
\hline
\end{tabular}

Keterangan : Nilai rata-rata perlakuan berdasarkan Uji T pada taraf nyata 5\%. ; BSP = Bulan Setelah Penanaman

lingkungan. Sedikitnya jumlah stomata yang terbuka, maka kemampuan tanaman dalam memfiksasi $\mathrm{CO}_{2}$ akan menurun. Hal tersebut akan berakibat pada penurunan laju fotosintesis, sehingga pertumbuhan akan terganggu. Sebaliknya jika konduktansi stomata besar, berarti jumlah stomata yang terbuka semakin banyak dan kemampuan tanaman dalam memfiksasi $\mathrm{CO}_{2}$ juga meningkat, sehngga laju fotosisntesis meningkat dan pertumbuhan akan semakin tinggi.

Tabel 5 menunjukkan bahwa diantara perlakuan konsentrasi pupuk hayati tidak menghasilkan konduktansi stomata yang berbeda nyata. Tidak berbedanya rata-rata antar perlakuan disebabkan variasi konduktansi stomata yang sangat beragam diantara perlakuan. Dengan demikian dapat dikatakan bahwa, konsentrasi pupuk hayati sampai batas konsentrasi 175 $\mathrm{mL} /$ tanaman tidak berpengaruh terhadap kemampuan proses fotosintesis tanaman padi gogo yang ditanam pada pertanaman kelapa sawit TBM 1.

Pertumbuhan tanaman kelapa sawit. Pertumbuhan kelapa sawit dan tanaman padi gogo varietas Situ Bagendit sebagai tanaman sela pada masa TBM 1 tidak menunjukkan kompetisi selama masa pertumbuhan tanaman. Hal ini ditunjukkan dengan data pada Tabel 6. Tinggi tanaman, jumlah daun, dan lilit batang tanaman kelapa sawit yang ditanam polikultur dengan tanaman padi sebagai tanaman sela, tidak menunjukkan pertumbuhan yang berbeda dengan tanaman kelapa sawit yang ditanam secara monokultur. Dengan demikian dapat disimpulkan bahwa, tanaman padi dapat ditanam secara tumpangsari pada pertanaman kelapa sawit TBM 1. Hal ini senada dengan hasil penelitian Suherman et al. (2019), tanaman kelapa sawit juga dapat ditanam secara sistem tumpangsari dengan tanaman jagung, tanpa mempengaruhi pertumbuhan tanaman kelapa sawit TBM I.

\section{Kesimpulan}

1. Dosis pupuk hayati berpengaruh terhadap jumlah gabah bernas (isi), bobot gabah per tanaman, dan bobot gabah 100 butir yang ditanam pada pertanaman kelapa sawit TBM 1.

2. Dosis pupuk hayati $100 \mathrm{~mL} /$ tanaman memberikan pengaruh cenderung baik terhadap karakter morfologis dan fisologis padi gogo varietas Situ Bagendit yang ditanam pada pertanaman kelapa sawit TBM 1 .

3. Penanam padi dapat ditanam sebagai tanaman sela pada pertanaman kelapa sawit TBM 1 dan tidak berpengaruh negative negatif terhadap pertumbuhan kelapa sawit TBM 1 . .

\section{Ucapan Terima Kasih}

Terima kasih kepada

1. Bapak Dr. Cucu Suherman yang telah membimbing dan mendanai penelitian ini dari skema PTUPT

2. Laboratorium Teknologi Benih dan Pemulian Tanaman, Fakultas pertanian, Universitas Padjadjaran, yang telah memfasilitasi alat dalam penelitian

\section{Daftar Pustaka}

Atmanegara, P, dan M. Bangun. 2013. Analisa Perbandingan Kandungan Klorofil menggunakan metode $\mathrm{M}$ cari dan $\mathrm{T}$ cari (Wilayah Studi : Kabupaten Karawang Jawa Barat). Fakultas Teknik Sipil dan Perencanaan Institut Teknologi Sepuluh Nopember Surabaya (ITS). Surabaya. Jurnal Teknik Vol. 2 (1).

Fawzy, Z.F., A.M. El-Bassiony, L. Yunsheng, O. Zhu, dan A.A. Ghoname. 2012. Effect of 
mineral, organik, and bio-N fertilizers on growth, yield, and fruit quality of sweet pepper. Journal of Appl. Sciences Research Vol.8 (8) : 3921-3933.

Ghoname, A. dan M.R. Shafeek. 2005. Growth and productivity of sweet pepper (Capsicum annuum L.) grown in plastic house as affected by organic, mineral and bio-N fertilizers, Journal of Agronomy Vol. 4 (4) : 369-72.

Kurniawan, M., M. Izzati, Y. Nurchayati. 2010. Kandungan Klorofil, Karotenoid, dan Vitamin C pada Beberapa Spesies Tumbuhan Akuatik. Buletin Anatomi dan Fisiologi Vol. 18 (1). Universitas Diponegoro, Tembalang, Semarang

Makarim, A. dan E. Suhartatik. 2009. Morfologi dan Fisiologi Tanaman Padi. Balai Besar Penelitian Tanaman Padi. Sukabumi. Subang.

Malgorzata, B., dan K. Georgios. 2008. Physiological response and yield of pepper plant (Capsicum annuum L.) to organic fertilization. Journal Central European of Agriculture Vol. 9 (4) : 715-722.

Reyes, I., L. Alvarez, El-Ayoubi, dan A. Valery. 2008. Selection and evaluation of growth promoting rhizobacteria on pepper and maize, Journal Bioagro, Vol. 20 (1) : 37-48.

Riyani, R., Radian, dan S. Budi. 2013. Pengaruh Berbagai Pupuk Organik terhadap Pertumbuhan dan Hasil Padi di Lahan Pasang Surut. Jurnal Sains Mahasiswa Pertanian Vol 2 (2), 1-11.

Simanungkalit, R.D.M. 2000. Apakah pupuk hayati dapat menggantikan pupuk kimia? Hal. 33 - 45: Suwarno, et al. (Eds.): Tonggak Kemajuan Teknologi Produksi Tanaman Pangan: Paket dan komponen Teknologi Produksi Padi. Simposium Penelitian Tanaman Pangan IV, Bogor, 22-24 November 1999. Puslitbangtan. Badan Litbang Pertanian

Suherman, C., A. Nuraini, Y. L. Batu, and M.A. Soleh. 2019. Utilize Open Space of Oil Palm (Elaeis guineensis Jacq.) Plantation at Immature Stages for Growing Maize (Zea Mays L.) which is Applied Biofertilizer.IOP
Conf. Series: Earth and Environmental Science 334 (2019) 012027

Suliasih, S. Widawati, dan A. Muharam. 2010. Aplikasi pupuk organik dan bakteri pelarut fosfat untuk meningkatkan pertumbuhan tanaman tomat dan aktivitas mikroba tanah. J. Hortikultura Vol 20 (2) : 241-246.

Sumarno, dan J.R. Hidajat. 2007. Perluasan areal padi gogo sebagai pilihan untuk mendukung ketahanan pangan nasional. Jurnal Iptek Tanaman Pangan Vol. 2(1): 26-40

Sumihar, S.T.T. 2012. Pengaruh Pupuk Hayati dan Kompos Tandan Kosong Sawit terhadap Pertumbuhan Bibit Kelapa Sawit (Elaeis guineensis Jacq.) di Pembibitan Awal. Lembaga Penelitian. Universitas HKBP Nommensen. Medan.

Suwandi dan R. Rosliani. 2004. Pengaruh kompos, pupuk nitrogen dan kalium pada tanaman cabai yang ditumpanggilir dengan Bawang merah. Jurnal. Hortikultura Vol 14 (1) : 41-48

Suwandi, G.A. Sopha, dan M.P. Yudy. 2015. Efektifitas pengelolaan pupuk organik, NPK, dan pupuk hayati terhadap pertumbuhan dan hasil bawang merah. Jurnal. Hortikultura Vol 25 (3) : 208-210

Wardhani, S., K. I. Purwani, dan W. Anugerahani. 2014. Pengaruh Aplikasi Pupuk Hayati Terhadap Pertumbuhan dan Produktivitas Tanaman Cabai Rawit (Capsicum frutescens L.) Varietas Bhaskara di PT Petrokimia Gresik.Jurnal Sains dan Seni Pomits. Vol. 2(1): 1-5

Widawati, S., Suliasih dan A. Muharam. 2010. Pengaruh kompos yang diperkaya bakteri penambat nitrogen dan pelarut fosfat terhadap pertumbuhan tanaman kapri dan aktivitas enzim fosfatase dalam tanah. Jurnal. Hortikultura Vol 20 (3) : 207-21

Zafar, M., N. Rahim, A. Shaheen, A. Khalik, T. Arjamand, M. Jamil, Z. Rehman, dan T. Sultan. 2011. Effect of combining poultry manure, inorganic phosphorous fertilizers, and phosphate solubilizing bacteria on growth, yield, protein content and $\mathrm{P}$ uptake in maize, $A A B$ Bioflux Vol. 3 (1) : 47-58. 